\title{
メダカの生殖・成長関連遺伝子群による 下水処理過程の生物影響削減効果の評価
}

\author{
北村友一 $^{1} \cdot$ 真野浩行 $^{1} \cdot$ 小森行也 $^{1} \cdot$ 岡本誠一郎 $^{1} \cdot$ 鈴木 $^{\text {穣 }^{2}}$ \\ 1正会員 国立研究開発法人土木研究所 水環境研究グループ テ305-8516 茨城県つくば市南原1-6 \\ Email:kitamura@pwri.go.jp \\ 2正会員 前土木研究所（現 国土技術政策総合研究所 下水道部 305-0804 茨城県つくば市旭1番地)
}

\begin{abstract}
魚類繁殖に関係する有性生殖，成長関連遺伝子群を選出し，メダカを試験魚とする96時間の曝露実験か ら, 活性污泥処理, 微生物保持担体処理での各遺伝子群の発現変動抑制効果の定量的評価を試みた。さら に，遺伝子発現レベルと産卵の関係解明のため, 両処理水についてメダカ成魚による産卵実験を行った. その結果，下水試料に曝露された試験魚の有性生殖，成長関連遺伝子群へ及ぼす影響は，曝露区と対照区 の試験魚の遺伝子発現強度の違いをユークリッド距離で示すことにより定量的に評価でき, 流入下水でみ られた有性生殖, 成長関連遺伝子群への影響は, 活性污泥処理, 後段の微生物保持担体処理により, 水生 生物の保全に係る水質環境基準の生物 $\mathrm{A}$ 類型の河川レベルまで低減された。 産卵実験からは両処理水の産 卵への悪影響は認められなかった。
\end{abstract}

Key Words : Medaka, Sexual reproduction, growth, Microarray, Sewage treatment process

\section{1. はじめに}

下水処理水の再利用の主要用途として, 河川維持用水, 修景用水が大きな割合を占めている. 今後, 再利用量も 増大していくと考えられ，また，意図的な再利用以外で も，都市河川では河川水に占める下水処理水の割合が高 くなると予想される，一方で，近年，水生生物一の影響 が確認されているエストロゲン類やその他の化学物質が 下水処理水中に残存していることが報告12)され，下水処 理水再利用先や放流先での水生生物一の影響が䀣念され ている. 水生生物の中で魚類は，水生生物の代表種，か つ, 資源生物であり，下水処理水の再利用先での生態影 響評価の優先順位は高く, 下水処理水や再生水の魚類生 態影響の実態や下水処理工程での影響低減効果を明らか にしておく必要がある.

魚類への影響は, 生態系保全を考慮すると, 魚類個体 群存続すなわち, 繁殖 (産卵, ふ化率, 稚魚の成長など) に関する項目で評価する必要がある. 魚類の繁殖試験は, 生殖, 成長, さらに, 次世代のこれらの影響まで考慮す ると流水式での長期間飼育が必要となり, 実駼施設の設 置が制約となったり, 処理水質に変動のある下水処理水
での試験結果の解釈が困難であったりする.こうしたこ とから, 下水処理水が魚類の繁殖に与える影響は未だ明 らかでない。

現在，胚・仔魚期の魚類を用いる短期毒性試験 ${ }^{3}$ から 下水処理水の毒性の実態把握や同定が始められている4 が，これは，胚や仔魚の生残率，才なわち繁殖影響の一 部を指標とするものである.

魚類個体群存続への影響を未然に防ぐために，下水処 理水や再生水の魚類への繁殖影響を短期間でモニタリン グできる方法が必要とされている.

近年, 化学物質の曝露から, 分子レベル, 細胞レベル, 臓器レベル，個体および個体群レベルへの影響について の反応経路 (Adverse Outcome Pathway; AOP ${ }^{5)}$ を整理し ていくことが重要とされ，AOPの一部である遺伝子発現 の知見の充実や遺伝子発現レベルの影響と個体レベルの 影響の関係解明が重要となっている．生体応答が早い 様々な機能の遺伝子発現を指標とするin vivo試験は, 遺 伝子発現レベルと個体レベルの関係についての知見が蓄 積されることにより，繁殖影響を短期間で推測できる可 能性がある.

下水処理水の魚類への安全性を遺伝子発現の変化から 
評価する場合, 繁殖に影響する遺伝子は多数存在すると 考えられ，これらの遺伝子発現の変化を一指標に統合し 定量的に評価する必要がある。これまでにも，下水試料 に曝露した魚類の遺伝子発現変動に着目した調査が行わ れているものの, その研究内容は発現変動遺伝子の機能 解析のやマーカーとなる特定の遺伝子の発現变動解析》で あり, 多数の遺伝子発現の変化に基づいた, 下水処理工 程での魚類繁殖影響の低減効果や処理水の繁殖影響レべ ルについて定量的な評価は行われていない.

そこで本研究では, 繁殖影響の評価に重要と考えられ る生殖, 成長関連遺伝子群を選出し, メダカを試験魚と し急性毒性試験と同じ96 時間の半止水式で化学物質, 下水試料, 河川水一の曝露実験を行い, マイクロアレイ を用いて, 生殖, 成長関連遺伝子群の各遺伝子発現強度 を取得した. 化学物質曝露試験は選出した遺伝子群の妥 当性評価, 下水試料曝露試験は下水処理工程での生殖, 成長関連遺伝子群の発現变動抑制効果の評価, 河川水曝 露試験は下水処理水の影響レベルを河川水と相対比較す るためとした. 生殖, 成長関連遺伝子群の各遺伝子発現 強度はユークリッド距離での定量的評価を試みた。

評価対象下水処理は, 活性污泥処理（二次処理）と, 二次処理水中に残存するエストロゲンや医薬品の除去効

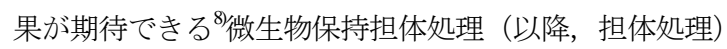
とした. さらに, 遺伝子発現レベルの影響と個体レベル の影響の関連を明らかにするため, 活性污泥処理水と担 体処理水については産卵実験を行った.

\section{2. 実験方法}

\section{（1）下水処理プロセス}

図-1に実験に使用した下水処理パイロットプラントの 概要を示す。実験装置は, 最初沈殿池（500L）, 活性污 泥処理槽 $(500 \mathrm{~L} \times 4$ 槽 $)$ ，最終沈殿池（700L），担体処 理槽 (40L) から構成されている. 流入下水は, 主に生活 排水が流入する実下水処理場の生下水を用いた。活性污 泥槽は, 第1槽から第4槽まで全面エアレーションを行う, 標準活性污泥法による処理とした. 水理学的滞留時間

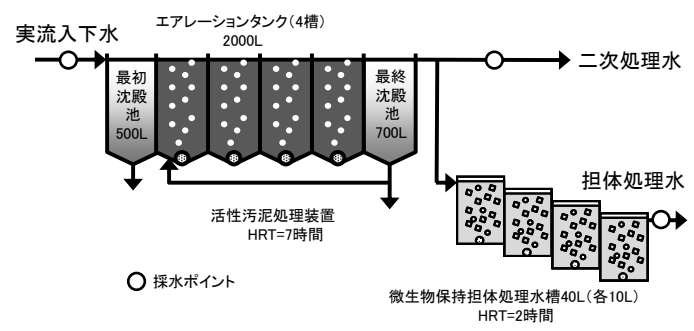

図-1 下水処理装置の概要
（HRT）は7時間程度である．担体処理槽は，微生物が 自然発生的に保持されたポリプロピレン製円筒担体 $(\phi$ $5 \mathrm{~mm}$, 長さ $5 \mathrm{~mm}$, 厚さ $1 \mathrm{~mm}$ ) が充填され, 水理学的滞留時 間2時間で二次処理水を処理した. メダカの曝露水は, 流入下水, 二次処理水, 担体処理水とし, 対照区は水道 水を活性炭処理した脱塩素水道水とした. 採水時期は, 2012年11月8～9日で，24時間連続採水とした.

\section{（2）メダカの 96 時間曝露実験と遺伝子発現解析の方法}

メダカの96時間曝露実験および遺伝子発現解析は, 表 -1の条件で行った. 性周期がなく遺伝子発現が安定して いる雄メダカでの評価を基本としたが，繁殖を考慮する 場合, 雌一の影響把握も必要と考えられるため, 下水処 理水曝露試験については, 雌メダカの曝露実験も追加し た. なお, 下水試料, 化学物質, 河川水の曝露実験は, 採水スケジュールの都合上，下水試料曝露と同時には行 えなかった。

解析対象臓器は肝臟とした。繁殖影響は生殖腺で解析 することも考えられるが，肝臓は多様な機能を担ってお り, 様々な生体影響を検出できると考えられること, 雄 魚の雌性化のマーカー遺伝子が肝臟において低エストロ ゲン濃度で誘導される9こと, 解析臓器を決定するため の予備実験(1)としてエストロンに曝露したメダカの肝臓 と精巣の遺伝子発現解析を行ったところ, 肝臓で繁殖関

表-1 メダカの曝露条件

\begin{tabular}{|c|c|}
\hline 試験魚 & $\mathrm{d}-\mathrm{rR}$ 系 ヒメダカ(6〜7カ月齢) \\
\hline 曝露匹数 & 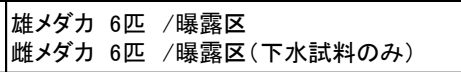 \\
\hline 曝露時間 & 96時間 \\
\hline 曝露水量 & $3 \mathrm{~L}$ \\
\hline 曝露方式 & 半止水式(1日1回全換水) \\
\hline 曝露下水試料 & \begin{tabular}{|l|} 
流入下水 \\
二次処理水 \\
担体処理水 \\
脱塩素水道水(対照区) \\
\end{tabular} \\
\hline 曝露化学物質 & \begin{tabular}{|l|} 
エストロン \\
クラリスロマイシン \\
塩化アンモニウム \\
脱塩素水道水(対照区)
\end{tabular} \\
\hline 曝露河川水 & $\begin{array}{l}\text { 河川水(生物類型AA地点) } \\
\text { 脱塩素水道水(対照区) }\end{array}$ \\
\hline 設定水温 & $24^{\circ} \mathrm{C}$ \\
\hline 照明 & 明期16時間/暗期8時間 \\
\hline 給䭒 & なし \\
\hline 曝気 & \begin{tabular}{|l} 
DOが低い試料は緩やかに懪気 \\
飽和溶存酸素濃度の50\%以上を確保
\end{tabular} \\
\hline 解析臓器 & 肝臟 \\
\hline RNA抽出法 & RNeay mini kitlよより1個体毎に抽出 \\
\hline RNA試料の調整 & $\begin{array}{l}\text { 下水試料では、同曝露区の2匹分を1つに混 } \\
\text { 合し、3検体で解析 (化学物質、河川水: 同曝 } \\
\text { 露区を、3匹分を1つに混合し2検体で解析) }\end{array}$ \\
\hline 遺伝子発現解析法 & マイクロアレイ法(Agilentのプロトコルに従う) \\
\hline 規準化法 & グローバルノーマライゼーション \\
\hline 遺伝子発現の数値化 & 発現強度を $\log _{2}$ 変換後、2または3検体を平均 \\
\hline
\end{tabular}


連遺伝子の発現変動が大きかったことから，肝蔵を選択 した.

遺伝子発現解析は, Agilent 製 8×60 Kのカスタムアレイ で実施した。ママイクロアレイ搭載遺伝子は，データベー

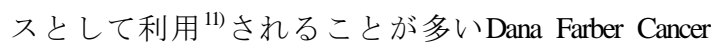
Institute (DFCI) ${ }^{12)}$ の Medaka Gene Index Release 8.0を基に, Agilentが提供しているプローブ配列設計ツール (e-Array) でプローブ配列を設計したものである. マイクロアレイ に搭載した遺伝子の機能は, DFCI のMedaka Gene Index サ イトからは十分に得られなかった. 生物影響を遺伝子の 機能別に解析するためには，遺伝子に機能情報を付加す る必要がある，遺伝子の機能は，NCBI (National Center for Biotechnology Information) が提供している類似配列検索プ ログラムの Blastx を利用した相同性検索から取得する方 法 ${ }^{13)}$ がある. 本研究では, NCBI のヒトのリファレンス シーケンス (Refseq) に対してプローブの基になったメダ 力配列を用いて Blastx で相同性検索を行い, ヒトの Refseq ID を取得した. 次に, Refseq ID を基に UniProt (Universal Protein Resource) のデータベースから，マイクロ アレイ搭載遺伝子にヒトのGene Ontology （遺伝子の機能 情報）を付加した.

Gene Ontology情報は, biological process（生物学的プロ セス）， cellular component（細胞の構成要素）， molecular function（分子機能）のカテゴリーに分類されるが, biological process の中から繁殖への影響が大きいと考えら れる sexual reproduction GO:0019953（有性生殖）, growth GO:0040007（成長）に属する遺伝子群を選出した. Gene Ontologyデータベースは，機能毎の階層構造になってお り，下層ほどより詳細な機能に分類される. sexual reproduction, growthの各下層に属する遺伝子も， sexual reproduction, growthのそれぞれに含めることとした.

選出した機能毎の遺伝子群の発現変動から, 影響を定 量的に評価するためには, 多数の遺伝子の発現情報から 1 つの指標を導出する必要がある. 指標として利用され る主なものには, ユークリッド距離とピアソン相関係数 がある ${ }^{14)}$. 1個のマーカー遺伝子で評価する場合, 対照 区との遺伝子発現倍率が指標とされるが，ユークリッド 距離はマーカー遺伝子が複数個のケースに拡張したもの であり，類似性評価の基本として広く利用されている. 本データでユークリッド距離とピアソン相関係数を算出 し比較したところ同様の結果が得られたが，ピアソン相 関係数は，遺伝子発現変動の大きさはあまり反映されな (15)ことが知られている. そこで，下水試料に曝露した メダカの機能毎の遺伝子群の発現強度から, 式 (1) に示 したユークリッド距離 (d) を用いて, 下水試料曝露区の, 対照区に対する類似性を数值化した. 算出された下水処 理工程水のユークリッド距離を処理工程間で比較するこ
とにより，下水処理工程での影響低減効果を評価した.

$$
\mathrm{d}=\sqrt{\sum_{i=1}^{n}\left(\mathrm{y}_{i}-\mathrm{x}_{i}\right)^{2}}
$$

ここで,

$\mathrm{x}=\left\{x_{1}, x_{2}, \ldots, x_{n}\right\}$ は対照区の遺伝子発現強度（ $\left.\log _{2}\right)$, $\mathrm{y}=\left\{y_{1}, y_{2}, \ldots, y_{n}\right\}$ は各曝露区の遺伝子発現強度（ $\left.\log _{2}\right)$ である.

\section{（3）化学物質曝露試験と河川水曝露試験}

sexual reproductionとgrowth関連遺伝子としてそれぞれ選 出された遺伝子群について，生物影響の判別性や定量性 を確認しておく必要があると考えられた，そこで，作用 機序の異なる複数の純物質の曝露試験から遺伝子発現パ ターンの違いや，濃度依存性を確認することとした．曝 露物質は，下水試料に高濃度で含まれ水生生物への影響 が懸念されている物質の中から，それぞれ作用機序が異 なると考えられるエストロン（E1），塩化アンモニウ ム $\left(\mathrm{NH}_{4} \mathrm{Cl}\right)$ ，クラリスロマイシンについて曝露実験を 行った.

E1は，エストロゲンの一種であることから sexual reproductionに強い影響を与えると考えられる. $\mathrm{NH}_{4} \mathrm{Cl}$ に 含まれる $\mathrm{NH}_{4}^{+}$は, 水生生物に対して急性, 慢性影響を有 することが知られ，魚類の産卵や成長にも影響するとの 報告 ${ }^{16)}{ }^{17}$ があり, sexual reproductionと growthに影響すると 考えられる. クラリスロマシンは，抗生物質であり藻類

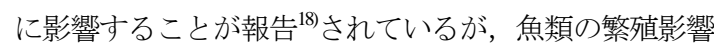
については明らかでない.

曝露濃度は，下水試料で存在する範囲 1) 19) 20) とし，E1 は，2，20，200 ng/L， $\mathrm{NH}_{4} \mathrm{Cl}$ は，3.2，10， $32 \mathrm{mg}-\mathrm{NH}_{4} / \mathrm{L}$ (2.5, 7.8, $25 \mathrm{mgN} / \mathrm{L})$ ，クラリスロマイシンは， 50, 500, 5000 ng/Lとした. E1, クラリスロマイシンはアセ トンで溶解した原液を作成し，一定量をガラス瓶に取り， アセトンを窒素吹付で完全に留去し, 脱塩素水道水を希 釈水として濃度調整を行った. $\mathrm{NH}_{4} \mathrm{Cl}$ は脱塩素水道水で 希釈した.

下水処理水を河川維持, 修景用水として再利用する上 で，繁殖影響を河川水と比較する必要があると考えられ たため, 水生生物の保全に係る環境基準の生物 $\mathrm{A}$ 類型に 指定されている多摩川上流の拝島橋付近の河川水も採水 し, 下水処理水との相対比較のための曝露試料とした. 河川水の採水は2013年1月30日にスポット採水した.

\section{(4) 水質分析の方法}

下水処理水と河川水の水質の確認と, 下水処理工程で の処理状況の把握，および，エストロゲンと無機態窒素 
濃度の遺伝子発現への影響との関係を考察するために, 下水処理工程水と河川水のDOC, $\mathrm{NH}_{4}-\mathrm{N}, \mathrm{NO}_{3}-\mathrm{N}$ 濃度を 測定し, E1とE2は固相抽出-GC/MS法 ${ }^{21)}$ で, クラリスロ マイシンは固相抽出-LC/MS/MS法2)で測定した.

\section{（5）二次処理水，担体処理水の産卵実験}

遺伝子発現レベルの影響と個体レベルの影響の関係解 明が重要であることから，二次処理水と担体処理水につ いては，メダカ成魚を用いた産卵実験を行った．実験期 間は96時間曝露実験の採水日の前後の約1力月間である。 曝露条件は，30 Lのガラス製水槽に6〜7カ月齢のメダカ 12 ペアを投入し, 給餌有, 水温 $26{ }^{\circ} \mathrm{C}$ での流水方式であ る. 対照区は脱塩素水道水とした. 曝露期間中は, 毎日, 各曝露区の受精, 未受精卵数を計数した.

\section{3. 実験結果と考察}

\section{(1) sexual reproductionとgrowth関連遺伝子の選出結果}

DFCIのMedaka Gene Indexのデータベースに登録されて いる遺伝子の中には, 同じ遺伝子が重複登録されている ものがあったため, 今回選出した sexual reproduction と growth 関連遺伝子の中にも, 同じGene symbolが付加され た遺伝子が重複して選出されていた，そこで，解析上の 重複を避けるため, 同じGene symbol が付加された遺伝 子は同一と見なし，相同性が最も高い遺伝子1つに統一 した.さらに，相同性を示す指標であるE-valueが0.01以 上となった遺伝子は相同性が低いと判断し解析対象遺伝 子から除外した. また，マイクロアレイのバックグラウ ンドノイズの影響を避けるため, 全下水試料曝露実験に

\section{表-2 sexual reproduction および growth 関連遺伝子のうち, ユークリッド距離算出に使用した遺伝子の一覧表}

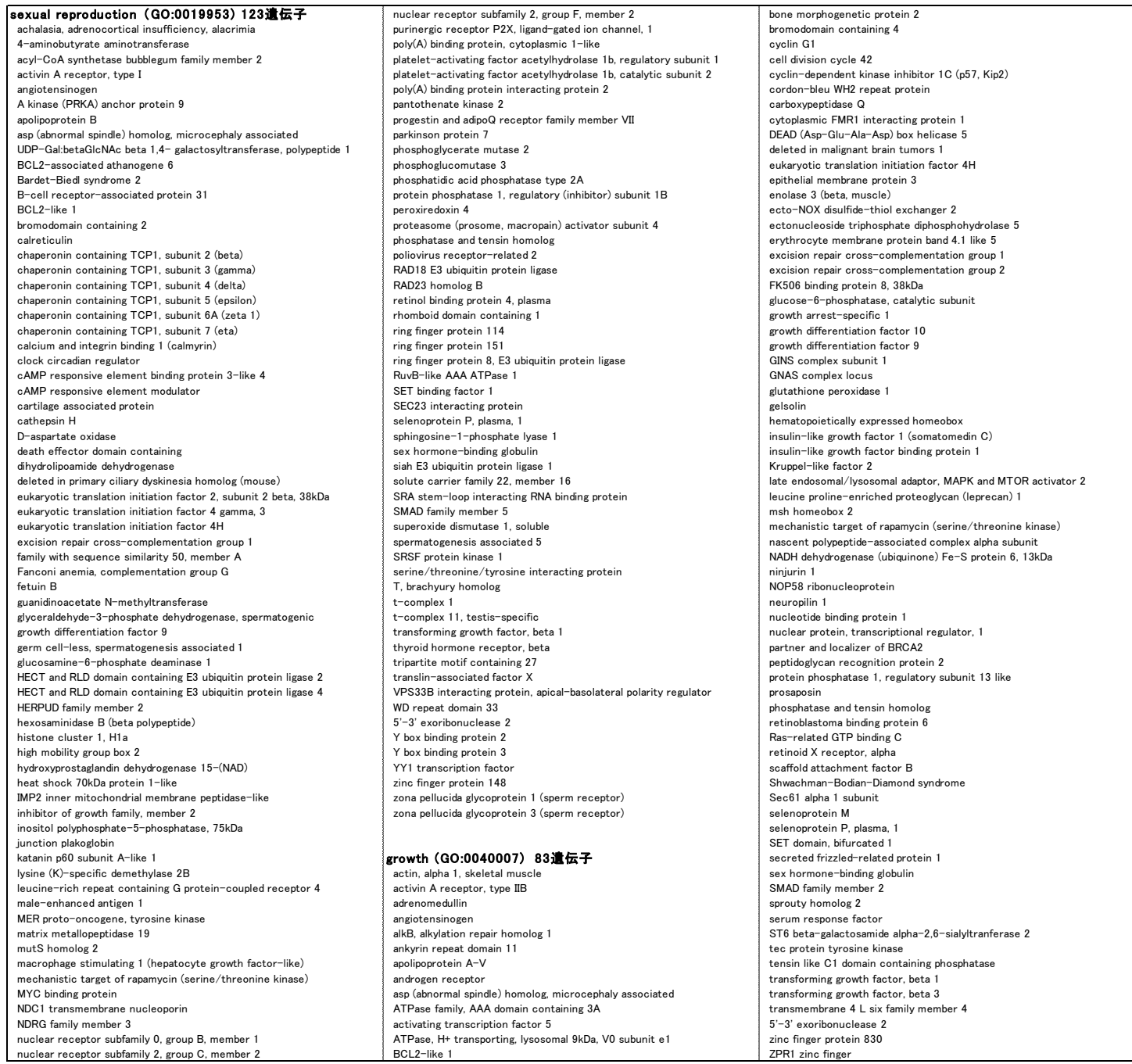


おいて，遺伝子発現強度がバックグラウンド以上の遺伝 子の夕を解析に使用した。 その結果, sexual reproduction 関連遺伝子123 個, growth関連遺伝子83個が選出された. 表-2にsexual reproduction およびgrowth関連遺伝子のHuman maker gene nameを示した.

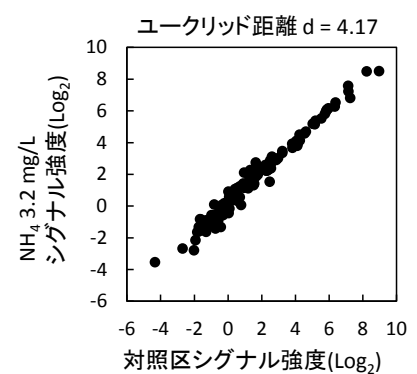

$3.2 \mathrm{mg}-\mathrm{NH}_{4} / \mathrm{L}$

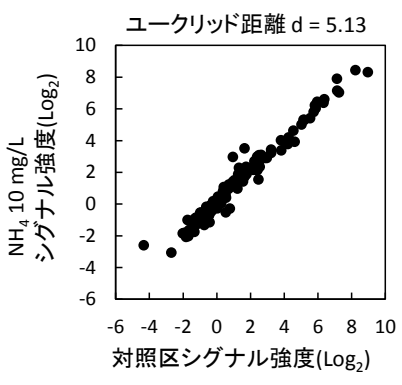

$10 \mathrm{mg}-\mathrm{NH}_{4} / \mathrm{L}$

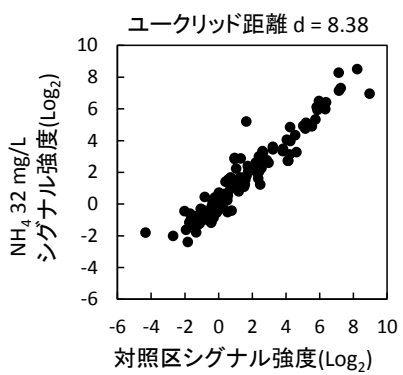

$32 \mathrm{mg}-\mathrm{NH}_{4} / \mathrm{L}$

図-2 $\mathrm{NH}_{4} \mathrm{Cl}$ 曝露区における, 対照区と曝露区の雄メダカ sexual reproduction 関連遺伝子群の発現強度の スキャッタープロットとユークリッド距離

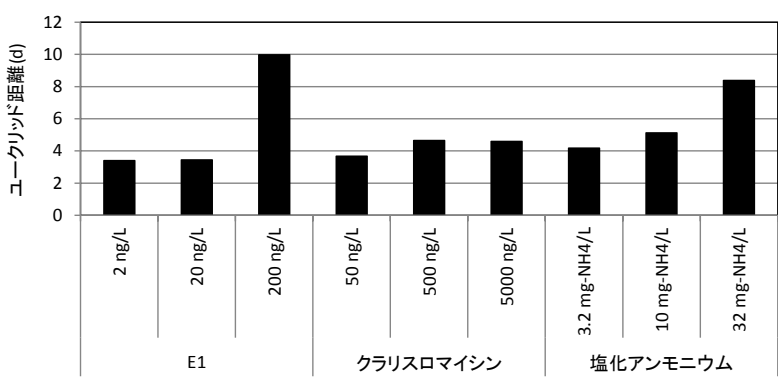

図-3 E1, クラリスロマイシン, 塩化アンモニウムの sexual reproduction への影響

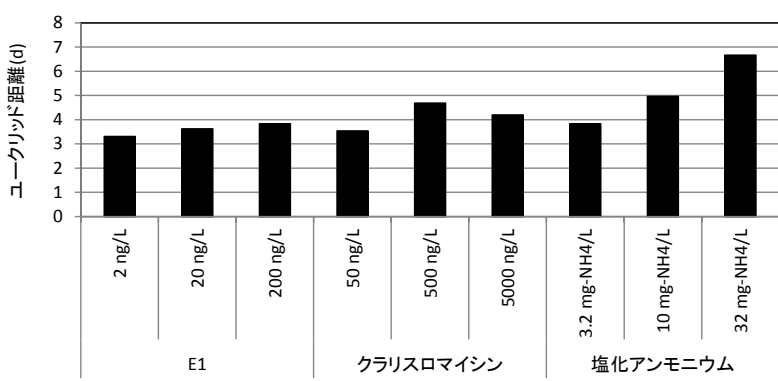

図-4 E1, クラリスロマイシン, 塩化アンモニウムの growthへの影響

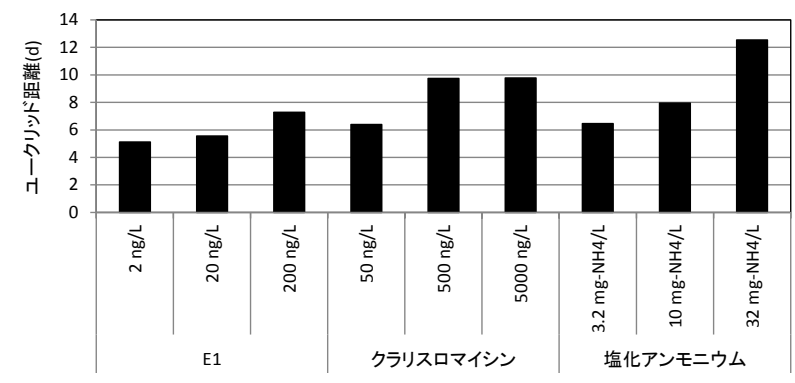

図-5 E1, クラリスロマイシン, 塩化アンモニウムの immune response への影響

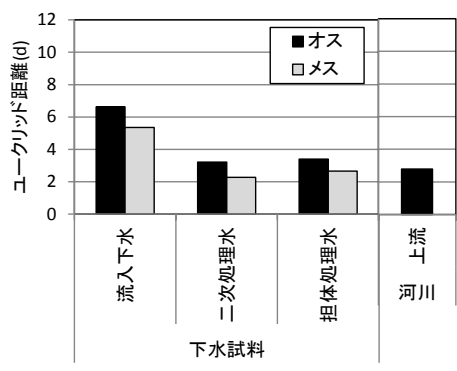

図-7 下水処理工程水, 河川水の sexual reproduction への影響

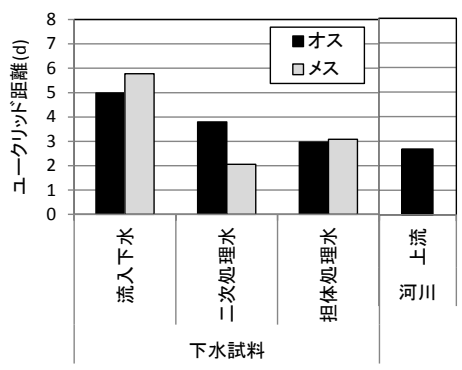

図-8 下水処理工程水, 河川水の growth への影響

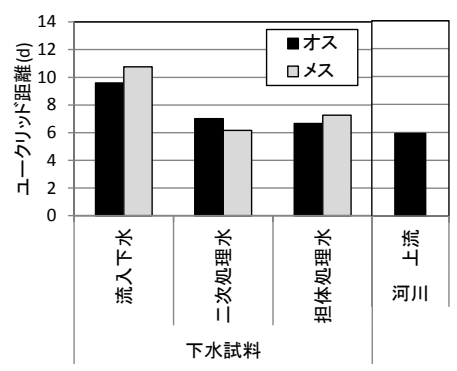

図-9 下水処理工程水, 河川水の immune response への影響 
(2) 化学物質曝露試験におけるsexual reproduction と growth への影響

図-2に， $\mathrm{NH}_{4} \mathrm{Cl}$ 曝露区のsexual reproductionの関連遺伝子 群の, 対照区に対する各曝露区の各遺伝子発現強度のス キャッタープロットとユークリッド距離を一例として示 した，図より，高濃度（32mg- $\mathrm{NH}_{4} / \mathrm{N} ）$ 曝露区では，低， 中濃度曝露区と比較すると, 対角線上から離れる遺伝子 が多いことがわかる．遺伝子発現への影響が小さい試料 では，遺伝子発現パターンが対照区と近くなっており， ユークリッド距離も小さい值をとることがわかる.

図-3に, 各化学物質曝露区のsexual reproductionのユーク リッド距離を示した. 図-4は, growthの結果である. sexual reproduction一の影響についてみると, E1 とアンモ ニアは濃度依存的に増加し, 特に, E1 $200 \mathrm{ng} / \mathrm{L}, \mathrm{NH}_{4} \mathrm{Cl}$ $32 \mathrm{mg}-\mathrm{NH}_{4} / \mathrm{L}$ 曝露区でユークリッド距離が大きく上昇し ていた. クラリスロマイシン曝露区では顕著な増加は確 認されなかった. growthへの影響についてみると, アン モニア曝露区でユークリッド距離が濃度依存的に上昇し ていた． E1，クラリスロマイシンでは顕著な増加は確 認されなかった. sexual reproduction と growth関連遺伝子群 から算出されたユークリッド距離は, 繁殖または成長影 響の定量的評価に利用できるものと考えられた.

クラリスロマイシンのsexual reproduction $と$ growth関連遺 伝子群以外の生物影響を確認するため, 薬物代謝（drug metabolic process）関連遺伝子を選び，ユークリッド距離 を求めたところ, 曝露濃度によらず変化は小さかった. クラリスロマイシン曝露区で遺伝子発現変動がみられた 遺伝子の機能を調べたところ, 免疫関連遺伝子一の影響 が確認された. 図-5は, immune response (GO:0006955) 関連 の283個の遺伝子から計算されたユークリッド距離であ る. immune responseへの影響は, クラリスロマイシン $500 \mathrm{ng} / \mathrm{L}, 5,000 \mathrm{ng} / \mathrm{L}$ 曝露区と $\mathrm{NH}_{4} \mathrm{Cl} 32 \mathrm{mg}-\mathrm{NH}_{4} / \mathrm{L}$ 曝露区で大 きな值を示した.

異なる遺伝子機能から算出されたユークリッド距離は, 化学物質の特性や濃度に応じた变化を示すことがわかっ た.

\section{(3) 下水処理工程水と河川水の水質分析結果}

図-6に下水処理工程水と河川水のDOC, $\mathrm{NH}_{4}-\mathrm{N}, \quad \mathrm{NO}_{3}-$
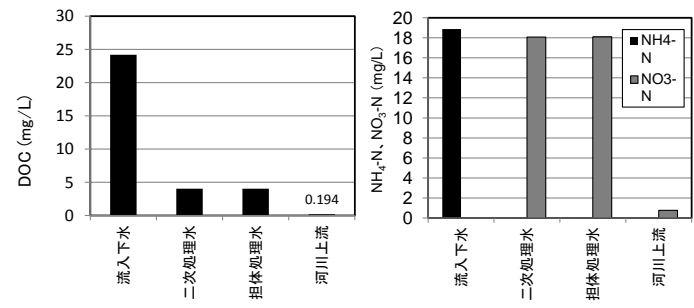

N，E1，E2，クラリスロマイシンの濃度を示寸．DOCは， 活性污泥処理で $83.3 \%$ \%゙除去され, 担体処理ではこれ以 上の除去はみられなかった. 流入下水中の $\mathrm{NH}_{4}-\mathrm{N} は$, 活 性污泥処理で $\mathrm{NO}_{3}-\mathrm{N} に$ 硝化され, 二次処理水, 担体処理 水でほとんど検出されなかった. E1, E2 2は, 活性污泥 処理で100\%近く除去されていた. クラリスロマイシン の除去率は, 活性污泥処理で $28 \%$, 担体処理まで含め ると $64 \%$ となった. 河川水のクラリスロマイシン濃度 は低レベルであった。

（4）下水処理工程水と河川水における sexual reproductionとgrowth への影響

図-7に, sexual reproductionについて下水処理工程水およ び河川水のユークリッド距離を示した，図-8は, growth の結果である. 図-9にimmune responseの結果を参考とし て示した。

sexual reproduction一の影響についてみると，下水試料 曝露区では, 雄と雌メダカとも流入下水曝露区で影響が 大きくなったが, 活性污泥処理で河川上流水と同レベル まで低減することがわかった。 河川上流水のユークリッ ド距離の值を影響がないレベルと仮定し，この值をべー スとして下水処理工程での影響の低減率を雄メダカの結 果から算出寸ると, 活性污泥処理で $89 \%$, 担体処理で は向上はみられなかった。この傾向は, DOC, E1，

$\mathrm{NH}_{4}-\mathrm{N}$ の除去と同様の傾向を示した.

growthへの影響についてみると, 雄と雌メダカとも流 入下水曝露区で影響が大きくなったが, 活性污泥処理で 低下していた．雄メダカでは, 処理の高度化に従い低下 し, 担体処理水は河川上流水と同レベルとなった.

sexual reproduction $と$ 同様に，下水処理工程での影響の低 減率を雄メダカの結果から算出すると, 活性污泥処理で $52 \%$, 担体処理を含めると $87 \%$ となった. 雄メダカで は, 担体処理は, growthへの影響の低減に寄与寸る結果 となった.

雌メダカでは, sexual reproduction, growth, immune responseでユークリッド距離が, 二次処理水と比較して 担体処理水で上昇していた. 特に, growthでその傾向は 顕著であった. ユークリッド距離の上昇に寄与している growthの下層機能を調べたところ, growth involved in
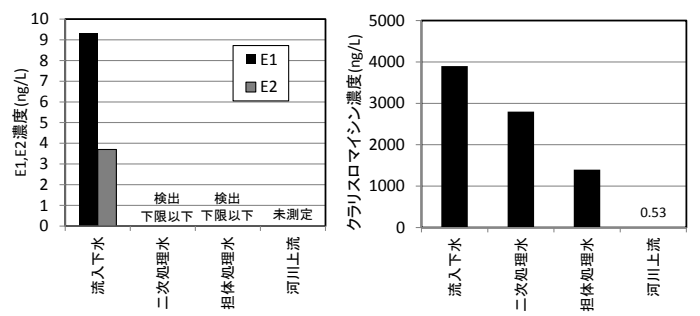

図-6 下水処理工程水と河川水の DOC, $\mathrm{NH}_{4}-\mathrm{N}, \mathrm{NO}_{3}-\mathrm{N}, \mathrm{E} 1, \mathrm{E} 2$, クラリスロマイシン濃度 
symbiotic interaction(GO:0044110)の寄与が大きいことがわか った。担体処理水曝露区の䧳メダカでこの機能が上昇し た理由については明らかにならなかった。

流入下水曝露区のユークリッド距離から算出された sexual reproductionとgrowthの影響レベルが，実際に個体に 影響が表れるレベルであったかどうかについては，今回 の実験から明らかにはならない，そこで，魚類へのE1 とアンモニアの曝露実験を行っている先行研究から考察 すると, メダカを試験魚としたE1の多世代曝露試験に おいて, E1 91ng/L以上で産卵数や受精率の低下, 生殖腺 には47 ng/Lでも影響が出る場合があったとの報告 ${ }^{23) か ゙ あ ~}$ る. 今回の実験での流入下水のE1濃度は9.3 ng/Lと低か ったが，E2は3.7 ng/L検出されていた，E1濃度に，E2濃 度を $\mathrm{E} 1$ 濃度に等量換算 ${ }^{24)} し た$ 值を加えると $\mathrm{E} 1$ 総量は63 ng/Lとなる. この濃度は，産卵数や受精率の低下には至 らないが，生殖腺組織に影響を与えるレベルを上回って いる.アンモニアについては，コイ科魚類でTotal ammonia-nitrogen $15 \mathrm{mgN} / \mathrm{L} （ 19 \mathrm{mg}-\mathrm{NH}_{4} / \mathrm{L} ）$ 以上で産卵数の 低下 ${ }^{16)}, 0.8 \mathrm{mgN} / \mathrm{L}\left(1 \mathrm{mg}-\mathrm{NH}_{4} / \mathrm{L}\right)$ でも成長阻害 ${ }^{17)}$ が生じ ることが報告されている。流入下水の $\mathrm{NH}_{4}-\mathrm{N} は ， 19$ $\mathrm{mgN} / \mathrm{L}(24 \mathrm{mg}-\mathrm{NH} / \mathrm{L})$ であり影響が生じるレベルを上回 っている，以上から，流入下水は，産卵や成長に影響が 生じるレベルであったと考えられる.

\section{(5) 二次処理水, 担体処理水の産卵実験の結果}

図-10に二次処理水，担体処理水の産卵実験での各曝 露水のDOC, $\mathrm{NO}_{3}-\mathrm{N}$, クラリスロマイシン濃度の結果と 雌1匹・1日当たりの累積受精卵数の変化を示した. 二次 処理水, 担体処理水の $\mathrm{NH}_{4}-\mathrm{N}$ 濃度は0.12 $\mathrm{mgN} / \mathrm{L}, \mathrm{E} 1, \mathrm{E} 2$ 濃度は0.7 ng/L以下であった. 図-8の水質分析結果には, 11月8～9日の24時間採水時の水質分析值も合わせて示し た，産卵実験期間中の各曝露区の水質は，概ね296時間曝 露実験の水質と同等であったと考えられる.

雌1匹・1日当たりの累積受精卵数は，二次処理水曝露 区で対照区より多い傾向を示し，担体処理水曝露区と対 照区の累積受精卵数はほぼ等しかった，対照区，二次処 理，担体処理曝露区の平均受精率は，それぞれ，63\%， $69 \%, 64 \%$ であり顕著な違いはみられなかった. 今回 の二次処理水, 担体処理水曝露区のsexual reproduction関 連遺伝子群から算出されたユークリッド距離のレベルは, 成魚の産卵には影響がないレベルであったと考えられる。

下水処理水を河川維持や修景に再生利用する場合，利 用先に生息する水生生物は再生水に曝露されるため, 水 生生物 の安全性を評価する手法が求められる. そのた め, 再生水の河川維持や修景利用に対して, sexual reproduction, growth関連遺伝子群から算出されるユーク リッド距離を用いた安全性評価を実施するための手法が

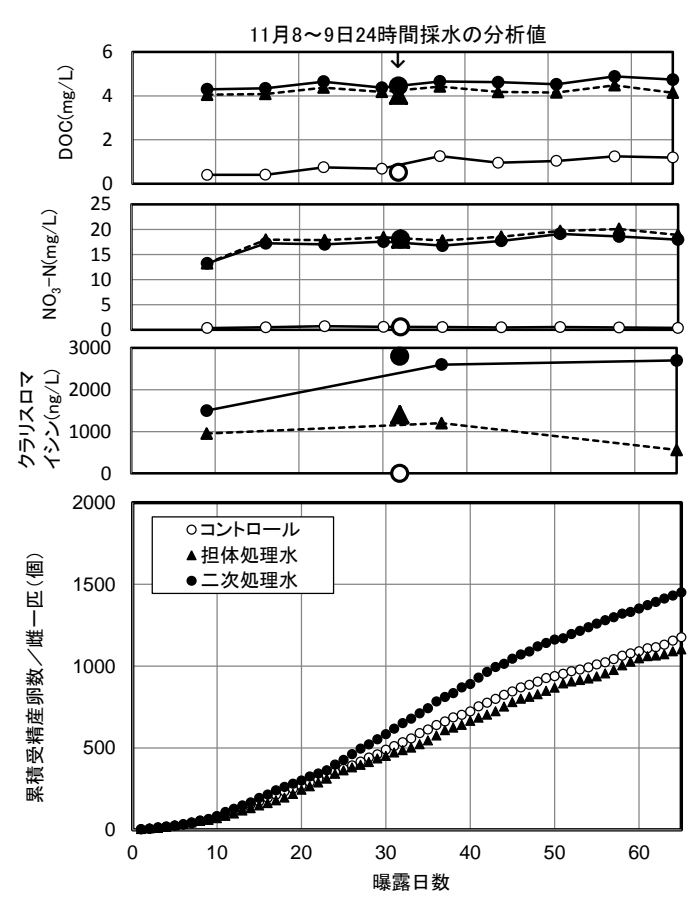

図-10 産卵実験での水質分析結果と

雌 1 匹.1 日当たりの累積受精卵数の変化

必要となる. 評価手法の1つとして再生水の利用用途ご とにユークリッド距離の基準值を導出することが考えら れる. 基準值の導出のためには, 影響の生じる濃度の化 学物質溶液または，安定した排水を用い，希釈段階を設 定し, 遺伝子発現と産卵, 仔稚魚の成長も含めたフルラ イフサイクルでの試験を同時並行で実施する必要がある。 しかしながら，膨大な時間と実験費用を要し簡単には行 えない. 代替案として，遺伝子発現を指標とした短期間 曝露による繁殖や成長影響の評価を, 評価対象とする再 生水と, 利用先として想定される環境水に適用し, 比較 することで, 利用用途ごとに再生水の安全性を相対的に 評価することが現時点では妥当と考えられる.

\section{4. おわりに}

下水処理水の再利用の主要用途として, 河川維持用 水, 修景用水が大きな割合を占め, 今後, 再利用量も増 大していくと考えられる. 下水処理水には魚類繁殖に影 響を与える物質が残存する場合があり，下水処理水の魚 類繁殖影響を短期間で推測するための方法が必要とされ ている. 本研究では, 繁殖に関係する生殖, 成長関連遺 伝子群を選出し, その遺伝子発現を指標として, メダカ を試験魚とする96時間の曝露実験から, 活性污泥処理, 
微生物保持担体処理での生殖, 成長関連遺伝子群の発現 変動抑制効果の評価を試みた。本研究で得られた成果を 以下に示寸.

1）下水処理工程水のメダカ繁殖への遺伝子レベルでの 影響は, ヒトの遺伝子機能情報から選出したメダカ のsexual reproductionやgrowth関連遺伝子群について, 下水試料曝露区と対照区の遺伝子発現強度の差異を ユークリッド距離で示すことにより，定量的に評価 できることがわかった.

2）化学物質曝露試験の結果より，E1 は sexual reproduction に, アンモニアは, sexual reproduction と growthどちらの遺伝子群にも影響を及ぼすことが確 認され、ユークリッド距離は化学物質の特性や濃度 に従った変化を示すことがわかった.

3）下水処理工程水と河川水の雄メダカの曝露試験の結 果より, 流入下水の sexual reproduction や growth $へ の$ 影響は，活性污泥処理で大きく低減され，後段に微 生物保持担体処理を追加することにより，水生生物 の保全に係る水質環境基準の生物 $\mathrm{A}$ 類型に指定さ れている河川レベルまで低減できることがわかった。

4) 二次処理水，担体処理水曝露区の sexual reproduction 関連遺伝子群から算出されたユークリッド距離のレ ベルは, メダカ成魚の産卵実験により, 産卵に影響 がないレベルであることが確認された.

謝辞 : 本研究は独立行政法人科学技術振興機構, CREST 戦略的創造研究推進事業「21世紀型都市水循環系の構築 のための水再生技術の開発と評価」の助成を受けて実施 した.ここに記して謝意を表す。

\section{参考文献}

1) K.Komori, H. Tanaka, Y. Okayasu, M. Yasojima and C. sato : Analysis and occurrence of estrogen in wastewater in Japan, Water Science \& Technology, 50(5), 93-100, 2004

2) 南山瑞彦, 小森行也, 北村友一, 鈴木穣, 岡安祐司：下 水道における生理活性物質の実態把握と制御に関する研 究, 土木研究所資料 平成 22 年度下水道関係調查研究年 次報告書集，pp. 195-224，2011

3）排水（環境水）管理のバイオアッセイ技術検討分科会 : 生物応答を用いた排水試験法（検討案），平成26年3月

4) 山本裕史, 矢野陽子, 森田隼平, 西家早紀, 安田侑右, 田村生 弥, 錿迫典久: 下水処理施設放流水中の残留塩素に着目し た毒性同定評価, 土木学会論文集G（環境），Vol.69, No.7, pp.375-384, 2013

5) Gerald T. Ankley; Richard S. Bennett; Russell J. Erickson; Dale J. Hoff; Michael W. Hormung; Rodney D. Johnson; David R. Mount; John W. Nichols; Christine L. Russom; Patricia K. Schmieder; Jose A. Semrano;
Joseph E. Tietge; Daniel L. Villeneuve : Adverse Outcome Pathways: a conceptual framework to support ecotoxicology research and risk assessment, Environ. Toxicol. Chem. 29(3), pp.730-741, 2010

6) Natalia Garcia-Reyeco, Candice M. Lavelle, B. Lynn Escalon, Dalma Martinovic, Kevin J. Kroll, Peter W. Sorensen, Nancy D. Denslow : Behavioral and genomic impacts of a wastewater effluent on the fathead minnow, Aquat. Toxicol., 101,pp.38-48, 2011

7) Filip Cuklev, Lina Gunnarsson, Marija Cvijovic, Erik Kristiansson, Carolin Rutgersson, Bemdt Björlenius, D.G. Joakim Larsson : Global hepatic gene expression in rainbow trout exposed to sewage effluents: A comparison of different sewage treatment technologies, Science of the Total Environment, 427-428, pp.106-114, 2012

8）小森行也, 岡本誠一郎 : 活性污泥処理プロセス及び微生物 担体処理プロセスにおける医薬品の除去特性, 第 51 回環境 工学フォーラム講演集, p.92-93,2014

9) Masaru Ihara, Tomokazu Kitamura, Vimal Kumar, Chang-Beom Park, Mariko O. Ihara, Sang-Jung Lee, Naoyuki Yamashita, Shinichi Miyagawa, Taisen Iguchi, Seiichiro Okamoto, Yutaka Suzuki, and Hiroaki Tanaka : Evaluation of Estrogenic Activity of Wastewater: Comparison Among In Vitro ER $\alpha$ Reporter Gene Assay, In Vivo Vitellogenin Induction, and Chemical Analysis, Supporting Information, Environ. Sci. Technol., 49(10),pp.6319-6326, 2015

10）池田茂, 南山瑞彦, 北村友一, 村山康樹, 朴永範 : 水生生物の 生体反応を用いた下水処理水の毒性評価に関する研究, 土 木研究所資料 平成 24 年度下水道関係調査研究年次報告 書集, pp.119-145, 2013

11）横田弘文 : 生態毒性用メダカマイクロアレイの開発, 第14 回バイオアッセイ研究会・日本環境毒性学会合同研究発 表会要旨,p.51,2008

12）http://compbio.dfci.harvard.edu/tgi/tgipage.html（最終チェック日 2013年2月6日)

13) Laura S.Robertson, Stephen D. McCormick : The effect of nonylphenol on gene expression in Atlantic salmon smolts, Aquatic Toxicology, 122123,pp.36-43, 2012

14）Issac S. Kohane, Alvin T. Kho, Atul J. Butte, 訳: 星田有人 : 統合ゲ ノミクスのためのマイクロアレイデータアナリシス, Springer-Verlag Tokyo, pp.128-129, 2004

15）岸克行 : 内分泌攪乱化学物質問題における分析ツールとし てのDNAマイクロアレイ,環境技術,36,11,p.787,2007

16) Brandon M. Armstrong, James M. Lazorchak, Cheryl A. Murphy, Herman J. Haring, Kathleen M. Jensen, Mark E. Smith : Determining the effects of ammonia on fathead minnow (Pimephales promelas) reproduction, Sci. Total Environ., 420, pp.127-133, 2012

17) Amit Kumar Sinha, Marjan Diricx, Lai Pong Chan, Hon Jung Liew, Vikas Kumar, Ronny Blust, Gudrun De Boeck : Expression pattem of potential biomarker genes related to growth, ion regulation and stress in response to ammonia exposure, food deprivation and exercise in 
common carp (Cyprinus carpio), Aquatic Toxicology, 122-123, pp.93105,2012

18) Arata Harada ,Koya Komori, Norihide Nakada, Kiyoaki Kitamura, Yutaka Suzuki : Biological effects of PPCPs on aquatic lives and evaluation of river waters affected by different wastewater treatment levels, Water Science and Technology, Vol.58, No.8, pp.1541-1546, 2008

19) Gopal Chandra Ghosh, Takashi Okuda Naoyuki Yamashita Hiroaki Tanaka : Occurrence and elimination of antibiotics at four sewage treatment plants in Japan and their effects on bacterial ammonia oxidation: water sci. technol. 59(4), pp.779-786, 2009

20）東京都下水道局 : 芝浦水再生センターにおける全空素流入 負荷に関寸る一考察, 東京都下水道局技術調查年報, 2008

21) Norihide Nakada, Hiroshi Nyunoya, Masaru Nakamura, Akihiko Hara, Taisen Iguchi, Hideshige Takada : Identification of estrogenic compounds in wastewater effluent. Environ. Toxicol. Chem., 23(12), pp.2807-2815.2004

22）小西千絵, 宝輪勲, 中田典秀, 小森行也, 鈴木穣, 田中宏明: 水 環境中医薬品のLC-MS/MSによる一斉分析法の検討, 環境 工学研究論文集, 43,pp.73-82,2006

23) Ataru Nakamura, Ikumi Tamura, Hitomi Takanobu, Masumi Yamauro, Taisen Iguchi, Norihisa Tatarazako : Fish multigeneration test with preliminary short-term reproduction assay for estrone using Japanese medaka (Oryzias latipes), J. Appl. Toxicol., 35(1),pp.11-23, 2015

24）北村友一, 真野浩行, 岡本誠一郎, 鈴木穣, 李相重, 山下尚之, 井原賢, 田中宏明, 小林憲太郎, 高畠寛生 : NF，RO膜処理に よるメダカ性特異遺伝子発現の変動抑制効果, 土木学会論 文集G（環境），Vol.70,No.7,pp.73-80,2014

(2015. 5. 22 受付)

\title{
EVALUATION OF TREATMENT PROCESS ON THE REDUCTION OF BIOLOGICAL EFFECT OF WASTEWATER WITH SELECTED GENE EXPRESSIONS FOR SEXUAL REPRODUCTION AND GROWTH IN MEDAKA
}

\author{
Tomokazu KITAMURA, Hiroyuki MANO, Koya KOMORI, Seiichiro OKAMOTO, \\ Yutaka SUZUKI
}

Biological effects of raw and treated wastewater were evaluated by selecting gene expressions for sexual reproduction and growth in male and female Medaka, and after 96 hour exposure to the samples by comparing the differences in the extent of the gene expressions between control and exposure in the form of Euclidian distance. In addition, reproduction tests using adult Medaka were carried out in the treated wastewater in order to clarify the relationship between the gene expression level and egg laying. As a result, by the treatment of activated sludge process and microbial carrier, biological effects evaluated by the gene expression were reduced to the level of a river with the category of Aquatic life A of the environmental quality standards for conservation of aquatic lives. Also, adverse effect of treated wastewater on the egg laying was not confirmed. 